\title{
Which subjects contribute to the teaching of cross-curricular topic Environmental Education at elementary schools in Czechia?
}

\author{
Tomáš Matějček ${ }^{1,2,3, *}$, Jan Bartoš1 ${ }^{1}$, Silvie R. Kučerová ${ }^{3}$
}

\author{
${ }^{1}$ Charles University, Faculty of Science, Department of Social Geography and Regional Development, Czechia \\ 2 Charles University, Faculty of Science, Department of Phyisical Geography and Geoecology, Czechia \\ 3 J. E. Purkyně University in Ústí nad Labem, Faculty of Science, Department of Geography, Czechia \\ * Corresponding author: tomas.matejcek@natur.cuni.cz
}

\begin{abstract}
This article summarizes the results of the research focused on the realization of the cross-curricular subject Environmental Education (CCSEE) at elementary schools (pupils' age 6-15 years) in Czechia. The introduction of cross-curricular subjects into the Czech educational system is linked to curricular reform and it has been implemented in Czech schools since 2007. CCSEE is one of the six currently implemented cross-curricular topics. The main objective of the present study is to determine which school subjects are involved in its implementation. The study was conducted through an internet questionnaire and responses were received from 640 schools. Data were processed by basic statistical methods. A school typology depending on the subjects involved in implementing EE was developed with the help of cluster analysis. The research shows that EE is implemented through most subjects, but their representation varies considerably for individual schools.
\end{abstract}

\section{KEYWORDS}

curricula; elementary school; geographical education; environmental education; cross-curricular subject; Czechia

Received: 11 July 2019

Accepted: 15 July 2020

Published online: 21 October 2020

Matějček, T., Bartoš, J., Kučerová, S. R. (2020): Which subjects contribute to the teaching of cross-curricular topic Environmental Education at elementary schools in Czechia?. AUC Geographica 55(2), 200-209

https://doi.org/10.14712/23361980.2020.14

(C) 2020 The Authors. This is an open-access article distributed under the terms of the Creative Commons Attribution License (http://creativecommons.org/licenses/by/4.0). 


\section{Introduction}

One of the changes brought to the Czech schools by Framework Educational Programs (FEPs) was the introduction of cross-curricular subjects. The cross-curricular subject Environmental Education (CCSEE) is one of them. The aim of the research presented here was to find out which school subjects are involved in the implementation of CCSEE in schools and to what extent, and whether it is possible to trace certain typical "models" of CCSEE implementation in terms of the involvement of individual school subjects. According to our professional orientation, we were especially interested in the role of geography in fulfilling the objectives of EE.

The development of EE in Czechia is clearly summarized by Máchal (2000) and Činčera (2013a, 2014). Putting into the international context is discussed in more detail in Činčera (2013b). The roots of EE can be found in the activities of volunteer organizations already in the interwar period of Czechoslovakia. These activities were followed by organizations working with children and youth in the 1970s (especially the Czech Union for Nature Conservation and the Brontosaurus Movement). The first centers of environmental education (Máchal 2000) were later established from these and other organizations.

However, the implementation of EE into formal (school) education was delayed in comparation with some countries of northern and western Europe. At present, the basic framework for EE at schools is based on the State Program of EE in the Czech Republic (approved in 2000). When planning EE implementation goals, schools are based on valid curricular documents (especially from FEP or school educational programs - see below), from the Methodological Guideline of the Ministry of Education, Youth and Sports on ensuring EE, from the regional concept of $\mathrm{EE}$ and their action programs, and from the analysis of specific school conditions. The CCSEE coordinator is designated at individual schools and is responsible for the fulfillment of EE objectives according to FEP. More authors mention that its evaluation is very important for the development of EE (Verma and Dhull 2017; Ssozi 2012; Ferguson 2008; Grodzińska-Jurczak 2004; Nam 1995).

CCSEE got into Czech curriculum documents in 2007 , in connection with the implementation of FEP (Jeřábek and Tupý 2007), which replaced the curriculum previously used. CCSEE is one of six currently implemented cross-curricular subjects. However, in the context of actual FEP revision, the future of cross-curricular topics is uncertain and actualy discussed.

According to Činčera (2005), the inclusion of CCSEE as a cross-curricular subject represents a major shift in its understanding in Czechia. Thus, EE started to be understood as a real cross-subject issue that integrates both the natural and human sciences. The expected outcomes for cross-curricular subjects (including CCSEE) were then elaborated in detail later (see Pastorová et al. 2011; Činčera 2011).

In practice, CCSEE can be implemented in schools either by integrating it into the educational content of existing school subjects, by creating a separate school subject or through project teaching (cross-curricular projects, project days). The individual forms may be combined with each other. The same situation is in Slovakia (Kelcová 2009). The opposite example is Great Britain (specifically England), where The Environemtal Curriculum gives examples of the implementation of EE in individual subjects (Green 2018).

Thus, all teachers in the school may theoretically participate in the implementation, but the situation in the individual schools may be quite different and the actual situation has not yet been closely monitored. This paper summarizes the results of research conducted at Czech elementary schools (primary schools) and focused on determining the degree of involvement of individual subjects in fulfilling the objectives of the EE, respectively. implementation of CCSEE.

In the past, this issue was only partially monitored, as part of the analysis carried out by Daňková et al. (2009). A wide range of aspects of EE goals implementation at schools was also addressed by a detailed study of Činčera et al. (2016), however, the rate of involvement of individual subjects was not realized in mentioned study. Finding out which subjects are involved in the implementation of EE can show whether EE really has a cross-curricular character and thus fulfills its potential.

EE can be realized in various forms and in various school subjects. The potential for implementing CCSEE objectives, introduced by FEPs (see Jeřábek and Tupý 2007), have practically all school subjects, but in different degrees. The interdisciplinary concept of EE prevails (Aikens et al. 2016). Number of concrete examples of linking environmental issues with other subjects, including fewer common ones, was described in the literature (see below).

In general, Godemann (2008) deals with integration and transdisciplinary concepts of environmental issues in a comprehensive way, which also summarizes the main principles of working with information in such a teaching approach. The importance of an interdisciplinary approach to EE is also highlighted by Jančař́́ková (2009).

The traditional is linking of EE with nature science education, especially with biology, physical geography and chemistry (Mwendwa 2017; Florentina and Barbu 2015; Ryplová and Reháková 2011; Řezníčková 2009). Aikens and McKenzie (2016) also state that most of the topics used in environmental education belong to the natural sciences, but recent studies are beginning to address the social sciences. Education in these school subjects enables pupils to know principles of natural processes, introduces them to the diversity of nature, and to understanding of the human activity impact on the natural environment. 
Yet some dichotomy can be observed in this respect as well. While nature science education was mainly motivated by the need to create a sufficiently strong scientific and technical base to accelerate innovation and strengthen competitiveness around the mid-20th century, EE which emerges in the 1960s as a response to the environmental crisis is in favor of the aim is to develop the environmental literacy necessary to understand the broader contexts from which these problems have arisen and are solved within them (Wals et al. 2014).

The possibilities of interconnection of EE with mathematics and physics, including concrete examples, are presented by Sýkora (2007), Melichar et al. (2006) and Palivec (2013). The possibilities of integrating EE and social sciences in the curriculum are addressed by the example of Nigeria by Adedayo and Olawepo (1997), Ferstl and Parkan (2007) summarize the possibilities of linking to history teaching.

Numerous suggestions for linking environmental issues with language and literature teaching was provided by Bowers (2010), which emphasizes the importance of using appropriate concepts in teaching environmental topics and introduces misconceptions that may result from the use of inexact terms. Possible reasons for children's concepts and misconceptions discusses Pavlátová (2019). Kubrická and Hromádka (2015) provided specific examples of the use of environmental topics for teaching English. The possibilities of linking EE with language and literature teaching are mentioned by Howard (2010), Lustyantie (2015) and Soetaert et al. (1996).

The importance of linking different forms of artistic activities with EE is dealt with by Dielman (2013). Navrátil (2012) presents on concrete examples the possibilities of fulfilling the goals and development of key competences of EE according to FEP, through artistic activities.

Various examples how to utilize works of art in geography and EE are also presented by Parkinson (2009), Vočadlová (2009) or Kučera (2012). Halocha (2008), Trojanová (2009), Řezníčková a Boháček (2010), Sánchez (2013), Quigley et al. (2014) show the possibilities of developing the skills of acquiring geographical or environmental information from image sources or photographs. Several options for integrating environmental topics can also be found in music education (Campos 2013; Váňová et al. 2007; Jurmu 2005) or in connection with drama education (McNaughton 2004). Integration with physical education can be realized primarily through field activities (Dechano and Shelley 2004).

\section{Research methodology}

Data collection was carried out by anonymous on-line questionnaire, which was addressed to the EE coordinators at most of all elementary schools in Czechia.
The questionnaire was created according to the principles for quantitative research (Gavora 2010; Chráska 2007).

The first part of the questionnaire was focused on the basic informations about the respondent (length of practice, sex, approbation), the second part was focused on the implementation of CCSEE. The questionnaire was sent out by a pilot survey (around 20 respondents), after this phase some items were changed or clarified. From the total number of primary schools to which the questionnaire was sent out (3203), we received responses from 640 respondents, after removing a few incomplete answers (return of about 20\%). The headmasters of the schools listed in the Atlas of Education database (http://atlasskolstvi .cz) were asked to send a request for forwarding to the EE school coordinator.

The length of teaching practice addressed by the EE coordinators varied from 1 year to 54 years. The average length of practice was 19.1 years, most respondents were women (86\%). The most frequent qualifications of respondents were biology, geography, chemistry, mathematics and physical education. Often repeated were different combinations of these school subjects.

The main part of the questionnaire consisted of items aimed at determining the rate of participation of individual school subjects in the implementation of CCSEE. For each school subject, respondents chose one of the following options: not involved or the subject is not taught at our school (0), very little (1), moderate (2), significantly (3), a core subject for achieving CCSEE objectives (4). A coefficient was assigned to each option (see above). This coefficient multiplied the frequency of individual responses in each category and the average was calculated. Thus it was found out how each subject participates in the realization of CCSEE.

The total dataset was divided into two parts, the first with answers of teachers who teach only at Stage 1 of elementary school $(n=153)$ and the second part with answers of teachers from complete (nine-year) elementary schools - with both Stage 1 and Stage 2 $(n=487)$.

To find out a typology of schools according to incorporation of the EE topics into the curriculum, it was necessary to choose the proper method. The metod would divide the objects (i.e. individual schools or better the answers of respondents from individual schools) into categories first according to composition of particular school subjects that comprise EE topics and second according to intensity of presence of EE topics (i.e. extent of the EE curriculum) within these subjects. Therefore, the multidimensional statistical method of hierarchical clustering was found as the most suitable for application. The method enables to divide the objects into categories according to mutual both similarity and dissimilarity of their characteristics. The analysis was conducted in the statistical software SPSS. 
The clustering of non-standardized variables was conducted. The variables were not standardized because all of them represent the same type of respondents' answers, originating from the same time period, therefore they don't vary in their values. During the hierarchical clustering the method of Average linkage between groups was applied to obtain maximal similarity within the groups together with the maximal dissimilarity between groups. The linkage of the variables (value of their distance) was measured with utilization of Pearson correlation intervals. Their utilization ensures that the structural similarity of the answers is preferred - in this case the proportion of frequency in appreciation of EE topics between individual school subjects by the respondents.

Since the number of input variables (i.e. number of school subjects) was too wide for such type of analysis, several groups of school subjects were created. At Stage 1, the appreciation of basic biology (originally prírodověda), homeland studies (originally vlastivě$\mathrm{da}$ ) and elementary teaching (originally prvouka) was observed. At Stage 2 biology, geography and health education were distinguished separately. The other subjects were grouped into: science subjects (physics, chemistry, mathematics), languages (mother language, foreign language), humane science subjects (history, civics), artistic and practical subjects (music, fine arts, physical education).

The number of 3 clusters was selected as the most representative number of clusters in the dataset of teachers at Stage 1 and 5 clusters in the dataset of teachers at complete elementary schools. The clusters were tested about their independency at 95\% confidence interval through comparison of their means by method One Way ANOVA.

\section{Results of Research}

The degree of involvement of individual school subjects in the implementation of EE objectives at primary schools with Stage 1 only, is shown in Figure 1. The predominance of science-related subjects is evident, but the role of fine arts and homeland studies (a subject with mainly geographical and historical content) is also significant.

The situation in complete (nine-year) elementary schools is shown in Figure 2. Biology is the most important subject in these schools, but geography, which is the second most important subject in this respect, also plays a significant role.

The educational objectives of CCSEE can be fulfilled not only in already existing school subjects, but also through a special separate school subject. One of the questions in the questionnaire survey was therefore focused on using this option. Results show that it is used by 114 schools (18\%). In about half of the cases the title of the subject contains the word ecology or ecological. In the remaining cases it is a modification of the subject of natural history or a practically conceived subject focused mainly on the realization of scientific experiments, research-oriented teaching, etc.

A simple typology of schools was based on the contribution to CCSEE goals fulfilling, assessed by respondents. The aim of this typology is to try to classify schools according to curriculum strategies of implementation EE goals.

Applying multivariate analytical statistical methods (cluster analysis) it was possible to distinguish 3 different clusters of elementary schools with the Stage 1 only according to the strategy of integrating

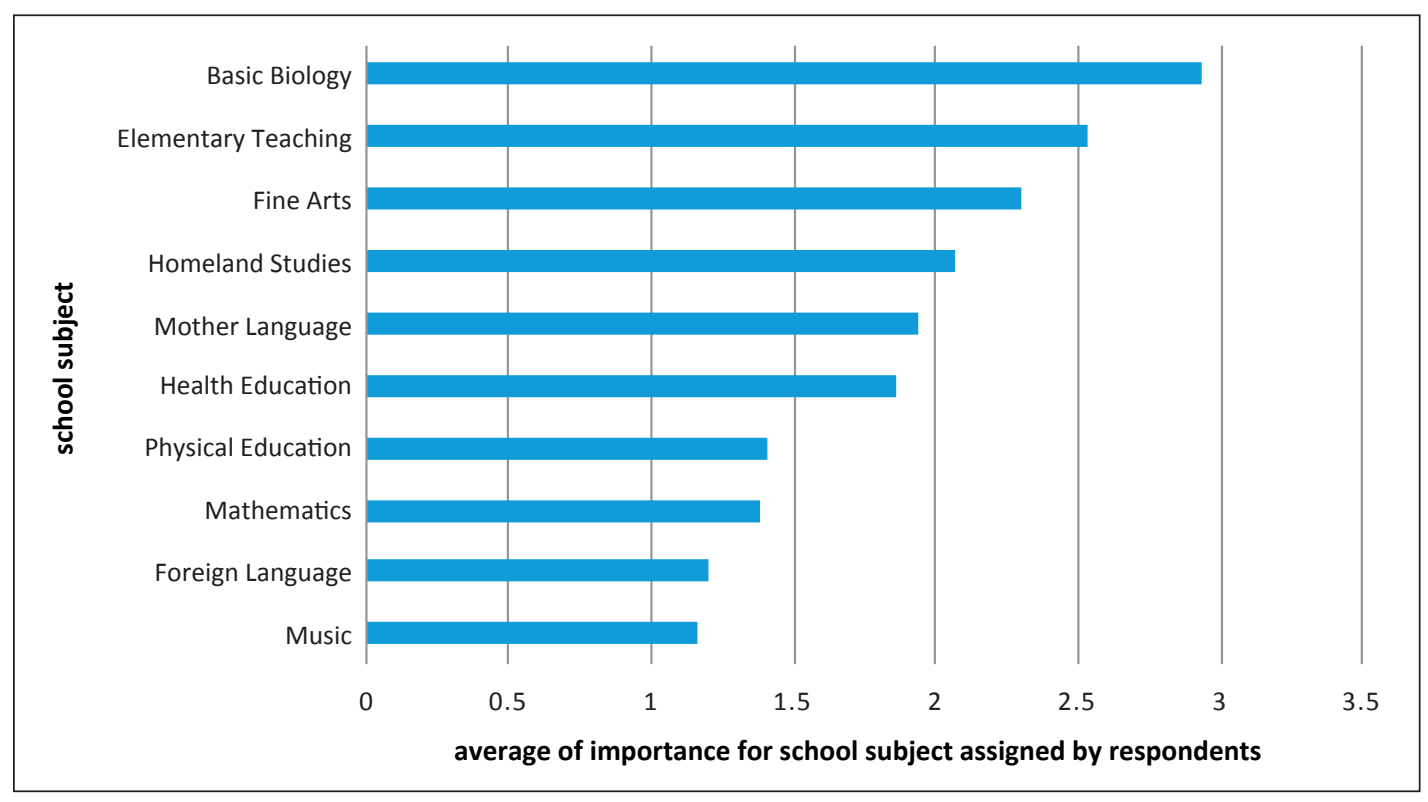

Fig. 1 The involvement of school subjects in the implementation of EE objectives at primary schools with Stage 1 only. 


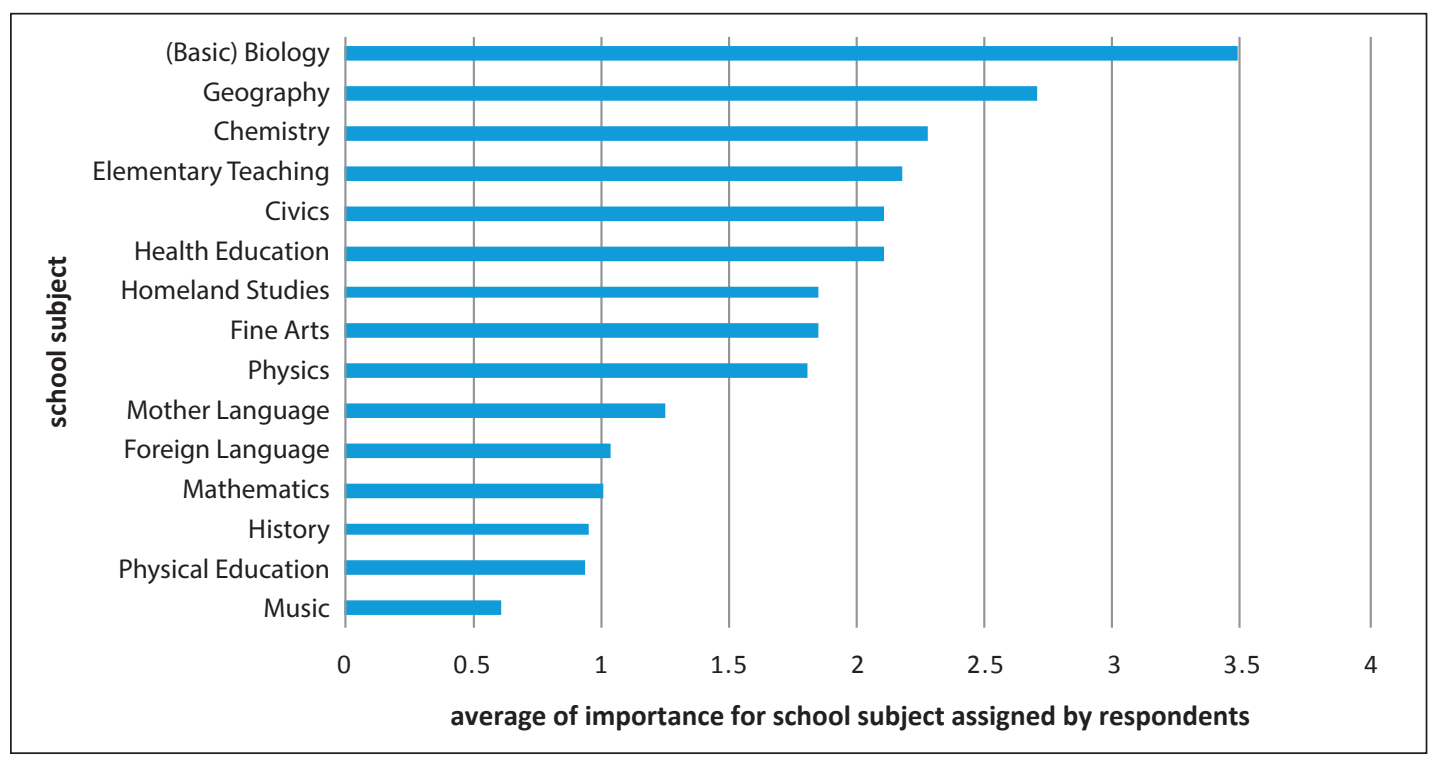

Fig. 2 The involvement of school subjects in the implementation of EE objectives at complete (nine-year) elementary schools.

the CCSEE into the curriculum. The first cluster includes those schools where the subject of basic biology contributes unambiguously to the implementation of CCSEE and in other school subjects this issue is almost not represented. Respondents in the second (most numerous) clusters assigned to the basic biology and previous school subject elementary teaching the same contribution. Homeland studies was also mentioned, but its role was less apparent. The third cluster is marked by a sharp decrease in the importance of basic biology for the implementation of CCSEE against the previous two. Elementary teaching and homeland studies contribute most to the CCSEE implementation. Nonetheless, respondents in the third cluster differ significantly, showing high values of the standard deviation (Table 1).

Five different clusters can be defined in a sample of complete elementary schools (Table 2). To better understand the types of EE inclusion strategies, we have identified them with working names (Table 3). The unifying element of the first cluster (separate subject) is the existence of a specific separate school subject for the implementation of CCSEE, although the valuation of other subjects varies widely within the set (see standard deviation values). Conversely, the second cluster (natural-geographic) includes schools where a separate subject of EE does not exist. Basic biology or biology and geography contribute most to CCSEE implementation. The third cluster (science subjects) also includes schools, where a separate subject focused on EE is not taught, but the role of basic biology or biology and geography is not prevailing. The wider group of natural science (mostly the importance of the subject of chemistry) and health education are the most involved in the implementation of CCSEE. However, this is the smallest cluster with a very low number of respondents (only 15). The fourth cluster was called socio-health. Although the importance of biology prevails, and also geography contributes to the realization of CCSEE, there is one of the highest evaluations of the contribution of human science subjects and health education to other statements. The last cluster was named complex because it was very difficult to determine the dominance of any subject in

Tab. 1 Descriptive statistics of clusters of schools with teaching at the Stage 1 only.

\begin{tabular}{|c|c|c|c|c|c|}
\multirow{2}{*}{ Cluster } & \multirow{2}{*}{$\begin{array}{c}\text { Number of schools } \\
\text { in cluster (N) }\end{array}$} & \multicolumn{4}{|c|}{ Average of importance for school subject assigned by respondents } \\
\cline { 3 - 6 } & 37 & separate subject & basic biology & homeland studies & elementary teaching \\
\hline 1 & 79 & 0.200 & 3.500 & 0.000 & 0.000 \\
\hline 2 & 37 & 0.000 & 3.600 & 2.900 & 3.600 \\
\hline 3 & & 0.600 & 0.900 & 2.300 & 2.700 \\
\hline 1 & & 0.917 & 0.605 & 0.000 & 0.000 \\
\hline 3 & & 0.000 & 0.481 & 0.938 & 0.485 \\
\hline
\end{tabular}


Tab. 2 Descriptive statistics of clusters of complete (nine-year) elementary schools.

\begin{tabular}{|c|c|c|c|c|c|c|c|c|c|}
\hline \multirow[b]{2}{*}{ Cluster } & \multirow{2}{*}{$\begin{array}{l}\text { Number } \\
\text { of schools } \\
\text { in cluster } \\
\text { (N) }\end{array}$} & \multicolumn{8}{|c|}{ Average of importance for school subject assigned by respondents } \\
\hline & & $\begin{array}{c}\text { separate } \\
\text { subject }\end{array}$ & $\begin{array}{l}\text { (basic) } \\
\text { biology }\end{array}$ & geography & $\begin{array}{l}\text { nature science } \\
\text { subjects }\end{array}$ & languages & $\begin{array}{l}\text { human science } \\
\text { subjects }\end{array}$ & $\begin{array}{c}\text { artistic and } \\
\text { practical subjects }\end{array}$ & $\begin{array}{c}\text { health } \\
\text { education }\end{array}$ \\
\hline 1 & 131 & 3.100 & 3.400 & 2.500 & 1.600 & 1.000 & 1.400 & 1.400 & 1.900 \\
\hline 2 & 161 & 0.000 & 3.900 & 3.100 & 1.800 & 0.900 & 1.400 & 1.500 & 2.000 \\
\hline 3 & 15 & 0.000 & 2.700 & 2.300 & 2.400 & 1.400 & 1.200 & 1.500 & 2.300 \\
\hline 4 & 155 & 0.100 & 3.200 & 2.400 & 1.600 & 1.400 & 1.800 & 2.100 & 2.600 \\
\hline 5 & 25 & 0.200 & 3.300 & 3.000 & 1.900 & 1.500 & 1.600 & 2.300 & 0.600 \\
\hline & & \multicolumn{8}{|c|}{ standard deviation } \\
\hline 1 & & 1.687 & 0.814 & 0.777 & 0.713 & 0.652 & 0.612 & 0.931 & 1.073 \\
\hline 2 & & 0.000 & 0.292 & 0.715 & 0.608 & 0.558 & 0.616 & 0.878 & 0.968 \\
\hline 3 & & 0.000 & 0.704 & 0.704 & 0.506 & 0.632 & 0.320 & 0.694 & 0.617 \\
\hline 4 & & 0.636 & 0.703 & 0.797 & 0.633 & 0.560 & 0.641 & 0.965 & 0.791 \\
\hline 5 & & 0.800 & 0.678 & 0.539 & 0.615 & 0.736 & 0.621 & 0.818 & 0.757 \\
\hline
\end{tabular}

Tab. 3 Elementary schools types according to a curricular strategy of realization of CCTEE in individual subjects at complete (nine-year) elementary schools.

\begin{tabular}{|c|l|l|l|}
\hline Cluster & Characteristics of type & Share from \\
\hline 1 & $\begin{array}{l}\text { schools with an separate subject environmental Education/EE, dominant in its contribution } \\
\text { to realization of CCTEE, although the appreciation of the others subjects on the participation } \\
\text { on CCTEE realization differs a lot }\end{array}$ & Separate subject \\
\hline 2 & $\begin{array}{l}\text { biology and geography are the most significant in realization of CCTEE, separate subject EE } \\
\text { is not taught }\end{array}$ & $\begin{array}{l}\text { Biological- } \\
\text { Geographical }\end{array}$ \\
\hline 3 & $\begin{array}{l}\text { various science subjects (chemistry the most of all) and health education as well contribute } \\
\text { to realization of CCTEE, separate subject EE is not taught }\end{array}$ & Science Subjects \\
\hline 4 & $\begin{array}{l}\text { biology or geography are the most significant in realization of CCTEE, nevertheless the highest } \\
\text { appreciation of humane sciences (civics the most of all) and health education is noticeable }\end{array}$ & $\begin{array}{l}\text { Humane-Health } \\
\text { educational }\end{array}$ & $3 \%$ \\
\hline 5 & $\begin{array}{l}\text { various subjects contribute to realization of CCTEE, including languages and fine arts, } \\
\text { nevertheless it is difficult to determine one dominant subject, on the contrary, health } \\
\text { education does not contribute to the realization of CCTEE at all }\end{array}$ & $32 \%$ \\
Complex & $5 \%$
\end{tabular}

CCSEE implementation. Biology and geography have been the most appreciated in this cluster, but values of languages and artistic and practical subjects (fine arts, physical education, music) are also very high in comparison with other clusters (although their meaning is very variable according to the standard deviation), and also science and social science subjects. This cluster is also relatively small ( 25 schools).

It seems that if the separate school subject of EE is not directly established, the biology and geography subjects contribute most to the implementation of CCSEE at Stage 2 of elementary school. Only when their role is weak, does health education, or chemistry and civics, hold this position.

\section{Discussion}

The research confirmed that CCSEE could be implemented in all school subjects. However, from the point of view of teachers some subjects seem more appropriate for its implementation. It can be seen from the results obtained that at the first level the primary role in the realization of CCSEE is played by the elementary teaching and natural science. This is due to the fact, that this subject is closely related to EE and also to the fact, that the EE is in Czechia still perceived as a synonym for ecology or ecological education (Máchal 2000), even among EE coordinators (Činčera 2013b). This is also confirmed by the finding that if a separate subject dedicated to EE is being taught at school, in half of the cases it include words ecology or ecological in its title. This corresponds to the results of Aikens et al. (2016), who also found that biological topics predominate in the implementation of EE.

At Stage 2 the second most important subject according to the share in the realization of CCSEE is geography. This subject (together with history, whose role in the implementation of CCSEE objectives did not prove too significant) follows the homeland studies 
that is taught at the Stage 1 and belongs among the most important subjects in terms of CCSEE implementation. The importance of geography in the implementation of EE mentions also Mwendwa (2017).

An analysis of the EU curriculum by Stokes et al. (2001) suggests that if EE is integrated into individual school subjects, it is most often in geography, science (the dominant role is played by biology, then chemistry and physics) and civics. This finding largely corresponds to the results of our research. In some countries, subjects labeled as technologies, which do not have a direct equivalent in the Czech education system, are also involved, their content and approach being spread across multiple subjects.

The importance of (basic) biology, geography and homeland studies, as well as civics and health education, was also confirmed by the results of cluster analysis. We can say that both natural and human science subjects are involved in the implementation of CCSEE. It corresponds to the understanding of EE according to Činčera (2005). Aikens et al. (2016) also cite that the importance of the social sciences for the realization of EE is slowly growing.

The results obtained are partly consistent with the results of Daňková et al. (2009), according to which the objectives of EE were fulfilled most often in chemistry ( $71 \%$ of schools), geography, civics, biology and subjects of Stage 1 (about one third of the schools surveyed). Similarly, Ruda (2010) mentions that pupils most often meet the adjective environmental in biology or natural history, geography and foreign language.

The observed share of schools with a separate optional subject focused on EE (18\%) roughly corresponds to the results of the analysis carried out by Daňková et al. (2009), according to which a single subject was taught to $14 \%$ of schools surveyed. However, the creation of a separate subject for the implementation of EE may not always be a good solution, as stated by Verma and Dhull (2017).

The aim of the presented research was to find out which subjects are involved in the implementation of CCSEE, but the specific forms and methods of teaching and the specific environmental topics taught have not been studied. This is one of the significant limitations of our study. However, these aspects are described in more detail in the studies of Bartoš and Matějček (2015) and Činčera et al. (2016), while the information about implementation of EE into individual subjects was just missing.

Another limit is the research sample. Although most schools in the Czechia were contacted, the return on the questionnaire was only partial. The representativeness of the results is thus limited to the schools that were willing to participated in the research. The informative value of the research is also limited by the fact that the results (due to various reasons) express only the view of teachers, which may differ from the real situation.
The choice of the way for the creation of clusters of the elementary schools may limit the results as well, because the outcoming groups from the clustering depend partly also on the method.

Important limits of research could also result from the ambiguity of the concept of EE itself. It is possible that teachers may have included in their responses activities that do not meet the objectives of EE or, conversely, did not have included activities that meet these objectives, even though they are not called as EE.

\section{Conclusions}

This research is the first comprehensive study primarily focused on the implementation of CCSEE in terms of the representation of individual subjects at Czech elementary schools. Results show that CCSEE is implemented at most Czech schools through most of existing subjects, but their representation and participation rates vary considerably across schools.

Approximately $18 \%$ of schools involved in our research have a separate subject dedicated to EE, which in some schools is dominant in terms of achieving CCSEE objectives, elsewhere it is only one of the subjects that fulfill these goals.

According to respondents, the subjects taught at Stage 1 are mostly represented by the elementary teaching, basic biology and homeland studies (school subjects focused on basic natural principles and their integration into the context of near neighbourhood of pupils. The relatively balanced role of these subjects in meeting CCSEE objectives at Stage 1 was also confirmed by the results of cluster analysis. The situation at the Stage 2 is a little more varied. However, similarly oriented subjects as biology and geography, also play a dominant role in fulfilling CCSEE objectives.

In addition to schools where the CCSEE goals are fulfilled dominantly by biology and geography (or are supplemented by a separate environmentally focused school subject), the results of cluster analysis have shown that other models of CCSEE implementation can exist at Czech elementary schools in practice. A more frequent case is the division of this role among a wider range of science subjects (chemistry, physics and mathematics, or health education, in addition to [basic] biology and/or geography), with less common subjects in almost all subjects, including artistic and practical ones, social sciences, languages, etc.

Although the implementation of Framework Educational Programs through CCSEE has reinforced the possibility of implementing EE in different subjects, including less traditional ones, the results of the survey show that a wider range of subjects is used only sporadically for this. We consider this finding a significant challenge for discussion.

From the geographical education point of view, the results are important especially as a confirmation 
of the importance of geography in the fulfillment of the objectives of the EE, respectively CCSEE. The fact that geography is one of the most important school subjects in terms of fulfilling these goals needs to be reflected more in particular in the preparation of future teachers of geography and in the further training of teachers, but also in textbooks and other didactic aids production, while specifying the expected outputs, evaluation of realized curriculum and its results, or in preparation of field competitions (for example Geographical Olympiad).

In addition to confirming the importance of geography for the implementation of EE topics (mentioned above), we consider the main result of our research to confirm the ability to meet the goals of EE through all school subjects. It demonstrates the usefulness of the concept of EE as a cross-curricular theme. Another important conclusion of our study, however, is the finding that the implementation of EE topics in many subjects is rather weak and occurs only in a relatively small number of asked schools.

During the processing of the results, several new questions emerged (see Table 4). Let these questions are taken as a contribution to the next discussion and as incentives for further research.

Tab. 4 Proposal of research questions for further research.

\begin{tabular}{|l|}
\hline - Which subjects do pupils associate with EE most often? \\
\hline $\begin{array}{l}\text { - Which forms of teaching predominate in the implementation } \\
\text { of EE in individual subjects? }\end{array}$ \\
\hline $\begin{array}{l}\text { - How different is the real concept of teaching EE topics compared } \\
\text { to curricular documents? }\end{array}$ \\
- To what extent is it appropriate to teach EE as a separate subject \\
(especially in terms of meeting the objectives of EE)? \\
\hline - How are teachers of various approbations prepared for the \\
implementation of EE topics? \\
\hline $\begin{array}{l}\text { - How EE implementations vary in different countries (international } \\
\text { comparison)? }\end{array}$ \\
- Which EE implementation models can be considered as inspiring \\
examples of good practice?
\end{tabular}

\section{Acknowledgements}

This article was supported by the research project of the Grant Agency of the Charles University No. SVV UK 260425 and the project PROGRES Q17 "Teacher Preparation and the Teaching Profession in the Context of Science and Research".

\section{References}

Adedayo, A., Olawepo, J. A. (1997): Integration of environmental education in social science curricula at the secondary school level in Nigeria: Problems and prospects. Environmental Education Research 3(1), 83-93, https://doi.org/10.1080/1350462970030107.
Aikens, K., Mckenzie, M., Vaughter, P. (2016): Environmental and sustainability education policy research: A systematic review of methodological and thematic trends. Environmental Education Research 22(3), 333-359, https://doi.org/10.1080/13504622.2015.11 35418.

Bartoš, J., Matějček, T. (2015): Rozvíjení environmentálních postojů z pohledu učitelů na 2. stupni základních škol. Envigogika 10(2), https://doi.org/10.14712/18023061 .475 .

Bowers, C. (2010): How language limits our understanding of environmental education. Environmental Education Research 7(2), 141-151, https://doi.org/10.1080 /13504620120043144.

Campos, H. G. (2013): La música y lo ambiental. Decisio, 12(34), 52-58.

Činčera, J. (2005): Environmentální výchova. Ale jaká? Pedagogická orientace 15(3), 17-24.

Činčera, J. (2011): Doporučené očekávané výstupy pro environmentální výchovu. Envigogika 6(2), https:// doi.org/10.14712/18023061.59.

Činčera, J. (2013a): Střediska ekologické výchovy mezi teorií a praxí. Praha, Brno: Agentura Koniklec, Brontosauří ekocentrum Zelený klub, Masarykova univerzita.

Činčera, J. (2013b): Paradigmatická proměna domácího pojetí environmentální výchovy. Pedagogika 63(2), 182-197.

Činčera, J. (2014): Environmentální výchova: cesty a křižovatky. Trenčín: Špirála.

Činčera, J., Jančaříková, K., Matějček, T., Šimonová, P., Bartoš, J., Lupač. J., Broukalová, L. (2016): Environmentální výchova z pohledu učitelů. Brno: Masarykova Univerzita, BEZK, Agentura Koniklec.

Daňková, L. et al. (2009): Analýza stavu environmentálního vzdělávání, výchovy a osvěty. Praha: Pavučina.

Dechano, L. M., Shelley, F. M. (2004): Using sports to teach geography: Examples from Kansas City. Journal of Geography 103(5), 185-191, https://doi.org/10.1080 /00221340408978599.

Dielman, H. (2013). El arte en la educación para la sustentabilidad. Decisio, 12(34), 11-16.

Farmer, J., Knapp, D., Benton, G. M. (2007): An elementary school environmental education field trip: Long-term effects on ecological and environmental knowledge and attitude development. Journal of Environmental Education 38(2), 33-42, https://doi.org/10.3200 /JOEE.38.3.33-42.

Ferguson, T. (2008): 'Nature' and the 'environment' in Jamaica's primary school curriculum guides. Environmental Education Research 14(5), 559-577, https://doi.org/10.1080/13504620802345966.

Ferstl, R., Parkan, F. (2007): Environmentální výchova ve výuce dějepisu. Metodika pro 2. stupeň ZŠ a víceletá gymnázia. Praha: Univerzita Karlova, Pedagogická fakulta.

Florentina, M., Barbu, M. (2015): An inter-disciplinary approach in teaching geography, chemistry and environmental education. Procedia - Social and Behavioral Sciences 180(1), 660-665, https://doi.org /10.1016/j.sbspro.2015.02.175.

Gavora, P. (2010): Úvod do pedagogického výzkumu. Brno: Paido. 
Godemann, J. (2008): Knowledge integration: A key challenge for transdisciplinary cooperation. Environmental Education Research 14(6), 625-641, https://doi.org/10.1080/13504620802469188.

Green, J. (Eds.). (2018): The Environmental Curriculum Opportunities for Environmental Education across the Secondary Curriculum Key Stages 3 and 4. Bath, NAEE (UK).

Halocha, J. (2008): Geography in the frame: Using photographs. Teaching Geography, 33(1), 19.

Grodzińska-Jurczak, M. (2004): Forum: Environmental Education in Poland: Its Present Status. International Research in Geographical and Environmental Education 13(3), 251-257, https://doi.org/10.1080 /10382040408668519.

Howard, P. (2010): Pedagogy and the poetic: Nurturing ecological sensibility through language and literature. Canadian Journal of Environmental Education 15(1), 185-197.

Chráska, M. (2007): Metody pedagogického výzkumu. Praha, Grada.

Jančaříková, K. (2009): Hledání optimální podoby realizace environmentální výchovy na prvním stupni ZŠ. Envigogika 4(1), https://doi.org/10.14712 /18023061.36.

Jeřábek, J., Tupý, J. (Eds.). (2007): Rámcový vzdělávací program pro základní vzdělávání. Praha: Výzkumný ústav pedagogický.

Jurmu, M. C. (2005): Implementing musical lyrics to teach physical geography: A simple model. Journal of Geography 104(4), 179-186, https://doi.org/10.1080 /00221340508978633.

Kelcová, M. (Eds.) (2009): Štátny vzdelávací program Environmentální výchova (Prierezová téma). Štátny pedagogicky ustav.

Kubrická, J., Hromádka, Z. (2015): Environmentální prvky v učebnici anglického jazyka. Envigogika 10(4), https://doi.org/10.14712/18023061.488.

Kučera, Z. (2012): Obraz jako zdroj rozmanitých informací. Geografické rozhledy 21(3), 18-20.

Lustyantie, N. (2015): Environmental education in the language and literature learning in elemetary education. International Journal of Research Studies in Education 4(3), 4-12, https://doi.org/10.5861/ijrse 2015.991.

Máchal, A. (2000): Průvodce praktikou ekologickou výchovou. Brno: Rezekvítek.

McNaughton, M. J. (2004): Educational drama in the teaching of education for sustainability. Environmental Education Research 10(2), 139-154, https://doi.org /10.1080/13504620242000198140.

Melichar, J., Hamerská, G., Fořtová, P. (2006): Soubor matematických úloh pro 1. stupeň základní školy environmentální výchova. Ústí nad Labem: Univerzita J. E. Purkyně v Ústí nad Labem, Pedagogická fakulta.

Mwendwa, B. (2017): Learning for Sustainable Development: Integrating Environmental Education in the Curriculum of Ordinary Secondary Schools in Tanzania. Journal of Sustainability Education 12, https://doi.org/10.25073/0866-773X/65.

Nam, S. J. (1995): Environmental Education in Primary and Secondary Schools in Korea: current developments and future agendas. Environmental Education
Research 1(1), 109-122, https://doi.org/10.1080 /1350462950010109.

Navrátil, 0. (2012): Prostor mezi environmentálním uměním a výchovou. Envigogika 7(2), https://doi.org /10.14712/18023061.72.

Palivec, Z. (2013): Průřezové téma Environmentální výchova ve výuce fyziky (Diplomová práce). České Budějovice: Jihočeská univerzita, Pedagogická fakulta.

Parkinson, A. (2009): Think inside the box. Miniature landscapes. Teaching Geography 34(3), 120-121.

Pastorová, M. et al. (2011): Doporučené očekávané výstupy: Environmentální výchova v základním vzdělávání metodická podpora. Praha: Výzkumný ústav pedagogický.

Pavlátová, V. (2019). Dětská pojetí vybraných environmentálních fenoménů u žáků 1 . a 2 . stupně základní školy. Envigogika 14(1), https://doi.org /10.14712/18023061.585.

Quigley, C. F., Miller, Z. D., Dogbey, J., Che, M. S., Hallo, J. (2014): No one should destroy the forest: Using photobased vignette interview to understand Kenyan teachers views of the environment. International Journal of Science Education 36(17), 2937-2957, https://doi.org /10.1080/09500693.2014.940024.

Ruda, A. (2010): Adjektivum „environmentální“ jako zaklínadlo geografického vzdělávání. In: Geografie pro život ve 21. století. In: Šumberová, M.: Sborník příspěvků z XXII. sjezdu České geografické společnosti pořádaného Ostravskou univerzitou v Ostravě 31. srpna - 3 září (s. 400-407). Ostrava: Ostravská univerizata $v$ Ostravě.

Ryplová, R., Reháková, J. (2011): Přínos badatelsky orientovaného vyučování (BOV) pro environmentální výchovu: př́ípadová studie implementace BOV do výuky na ZŠ. Envigogika 6(3), https://doi. org/10.14712/18023061.65.

Řezníčková, D. (2009): The transformation of geography education in Czechia. Geografie 114(4), 316-331, https://doi.org/10.37040/geografie2009114040316.

Řezníčková, D., Boháček, T. (2010): Čtení fotografií optikou geografa. Geografické rozhledy 19(4), 18-19.

Sánchez, D. M. G. (2013): De la tierra evocada a la tierra presentada. La fotografía como medio para la educación ambiental. Decisio 12(43), 46-51.

Siwek, T. (2010): Současná geografie očima českých geografů. Geografie 115(4), 361-376, https://doi.org /10.37040/geografie2010115040361.

Soetaert, R., Top, L., Eeckhout, B. (1996): Art and literature in environmental education: Two research projects. Environmental Education Research 2(1), 63-70, https:// doi.org/10.1080/1350462960020106.

Ssozi, L. (2012): Embedding Education for Sustainability in the School Curriculum: the contribution of Faith Based Organisations to Curriculum Development. Journal of Sustainability Education, vol. 3.

Stokes, E., Edge, A., West, A. (2001): Environmental education in the systems of the European Union. Final Report. London: Environment Directorat-General of the European Commission.

Sýkora, V. (2007): Environmentální výchova v práci učitele matematiky. Praha: Univerzita Karlova, Pedagogická fakulta. 
Trojanová, A. (2009): Využití land artu ve výuce. Geografické rozhledy 18(4), 20.

Váňová, H., Tichá, A., Herden, J. (2007): Environmentální výchova ve výuce hudební výchovy v základním vzdělávání. Praha: Univerzita Karlova, Pedagogická fakulta.

Verma, G., Dhull, P. (2017): Environmental education as a subject in schools. International Journal of Advanced
Research 5(8), 1547-1552, https://doi.org/10.21474 /IJAR01/5214.

Vočadlová, K. (2009): Obrazy jako archiv přírodních změn. Geografické rozhledy 18(5), 24-26.

Wals, A. E. J., Brody, M., Dillon, J., Stevenson, R. B. (2014): Convergence between science and environmental education. Science 344(6184), 583-584, https:// doi.org/10.1126/science.1250515. 